\title{
Biological evidence for a causal role of HPV16 in a small fraction of laryngeal squamous cell carcinoma
}

\author{
G Halec $^{\star, 1}$, D Holzinger ${ }^{1,2}$, M Schmitt ${ }^{1}$, C Flechtenmacher ${ }^{3}$, G Dyckhoff $^{2}$, B Lloveras ${ }^{4}$, D Höfler ${ }^{1}$, \\ $\mathrm{F} X$ Bosch $^{2}$ and M Pawlita ${ }^{1}$ \\ ${ }^{1}$ Division of Genome Modifications and Carcinogenesis, Infections and Cancer Program, German Cancer Research Center, \\ Im Neuenheimer Feld 242, 69120 Heidelberg, Germany; ${ }^{2}$ Molecular Biology Laboratory, Department of Otolaryngology, Head \\ and Neck Surgery, University of Heidelberg, Im Neuenheimer Feld 400, 69120 Heidelberg, Germany; ${ }^{3}$ Institute of Pathology, \\ University of Heidelberg, Im Neuenheimer Feld 220, 69120 Heidelberg, Germany and ${ }^{4}$ Hospital del Mar, Parc de Salut Mar, and \\ Catalan Institute of Oncology, 08003 Barcelona, Spain
}

Background: Human papillomavirus (HPV) is a causal factor in virtually all cervical and a subset of oropharyngeal squamous cell carcinoma (OP-SCC), whereas its role in laryngeal squamous cell carcinoma (L-SCC) is unclear.

Methods: Formalin-fixed paraffin-embedded $(N=154)$ and deep-frozen tissues $(N=55)$ of 102 L-SCC patients were analysed for the presence of 51 mucosal HPV types. HPV DNA-positive (HPV DNA +) cases were analysed for E6*I mRNA transcripts of all high risk (HR)/probably/possibly (p)HR-HPV identified, and for HPV type 16 (HPV16) viral load. Expression of p16 INK4a, pRb, cyclin D1 and $p 53$ was analysed by immunohistochemistry.

Results: Ninety-two patients were valid in DNA analysis, of which $32(35 \%)$ had at least one HPV DNA + sample. Among the 29 single infections, 22 (76\%) were HPV16, 2 (7\%) HPV56 and 1 each (4\%) HPV45, HPV53, HPV70, HPV11 and HPV42. Three cases harboured HPV16 with HPV33 (twice) or HPV45. Only 32\% of HPV DNA + findings were reproducible. Among HPV16 DNA+ L-SCC, 2 out of $23(9 \%)$ had high viral loads, 5 out of 25 (21\%) expressed E6*I mRNA and 3 out of $21(14 \%)$ showed high p16 ${ }^{\text {INK4a }}$ and low pRb expression (all three HPV16 RNA-positive), immunohistochemical marker combination not identified in any other HPV DNA + or HPV DNA-negative (HPV DNA - ) L-SCC, respectively.

Conclusion: HPV type 16 has a causative role in a small subgroup of L-SCC $(<5 \%$ in this German hospital series).

Laryngeal squamous cell carcinoma (L-SCC) accounts for almost $2 \%$ of all malignancies worldwide, and together with oropharyngeal squamous cell carcinoma (OP-SCC) is the most common cancer type arising in the head-and-neck ( $\mathrm{HN}$-)region. In the past two decades, epidemiological and biological studies demonstrated that human papillomavirus (HPV), especially HPV type 16 (HPV16), has an aetiological role in a subset of OP-SCC located mainly in proximity to the lymphoid tissues of Waldeyer's ring such as tonsils and base of the tongue. Human papillomavirusdriven OP-SCC exhibit presence of HPV DNA with high viral loads (Mellin et al, 2002; Jung et al, 2010; Holzinger et al, 2012), transcriptionally active virus (van Houten et al, 2001; Wiest et al, 2002; Braakhuis et al, 2004; Lindquist et al, 2007), and frequently show high expression of $\mathrm{p} 16^{\mathrm{INK} 4 \mathrm{a}}$ (Reimers et al, 2007; Hoffmann et al, 2010; Rischin et al, 2010; Hoffmann et al, 2012), a robust surrogate marker for HPV involvement in cervical cancer ( $\mathrm{CxCa})$. Importantly, patients with HPV-driven OP-SCC are characterised by better overall and disease-free survival (Andl et al, 1998; Jung et al, 2010; Holzinger et al, 2012).

In laryngeal carcinogenesis, tobacco smoking and alcohol consumption are recognised as the major risk factors (Muscat and Wynder, 1992). Human papillomavirus DNA prevalences

*Correspondence: Dr G Halec; E-mail: g.halec@dkfz.de

Received 11 March 2013; revised 16 May 2013; accepted 21 May 2013; published online 18 June 2013

(c) 2013 Cancer Research UK. All rights reserved 0007-0920/13 
ranging from 3 to $60 \%$ have been reported (Perez-Ayala et al, 1990; Almadori et al, 1996; Gungor et al, 2007; Morshed et al, 2008); however, consistent biological evidence for viral involvement in L-SCC is still lacking. Varying HPV DNA prevalence reported across different epidemiological studies can be attributed to geographical differences, inadequate separation of laryngeal carcinoma cases from other cancers of the HN-region, for example, the OP-SCC, differences in analytical sensitivity of HPV-genotyping methods applied and limited spectrum of HPV types analysed. Currently, of 51 mucosal HPV types known today for $\mathrm{CxCa}$ (Bernard et al, 2010), 12 are classified as carcinogenic or high-risk (HR)-HPV (HPV16, 18, 31, 33, 35, 39, 45, 51, 52, 56, 58 and 59), 8 as probably/possibly carcinogenic or (p)HR-HPV (HPV26, 53, 66, $67,68,70,73$ and 82 ) and 31 as types of low/undetermined carcinogenicity or LR-HPV (IARC, 2011). Most of the studies analysed L-SCC samples for the presence of only the five HR-HPV types 16, 18, 45, 31 and 33 that are most frequent in $\mathrm{CxCa}$ (reviews (Kreimer et al, 2005; Torrente et al, 2011) and references therein), with HPV16 predominating. Few case reports identified pHRHPV73 and 82 DNA in L-SCC by direct sequencing technology (Pannone et al, 2010; Si-Mohamed et al, 2012). The LR-HPV6 and 11 have been reported more frequently especially in association with recurrent respiratory papillomatosis (Syrjanen et al, 1987; Salam et al, 1995).

Human papillomavirus DNA alone is not sufficient to identify HPV-driven cancers as has become evident for OP-SCC (Jung et al, 2010; Holzinger et al, 2012). High-risk-HPV DNA has been found in benign and normal tissue of the larynx (Garcia-Milian et al, 1998; Duray et al, 2011), supporting the idea that HPV DNA presence alone cannot demonstrate causality. The concept for causal involvement of mucosal HPV in the pathogenesis of SCC includes: (a) presence of at least one viral genome copy per tumour cell, (b) active transcription of the viral oncogenes E6 and E7 and (c) interaction of the viral oncoproteins with central cellular regulator proteins of cell cycle and apoptosis signalling (Dyson et al, 1989; Scheffner et al, 1990; zur Hausen, 2006). Such systematic analysis for biological HPV involvement in L-SCC are still missing. Three studies addressing the question of HPV causality used a limited set of markers (HPV16 mRNA and p16 expression) and indicated the existence of a small fraction of laryngeal cancers with active HPV involvement (Schlecht et al, 2011; Chernock et al, 2012; Lewis et al, 2012).

To clarify the biological role of HPV in laryngeal carcinogenesis, we systematically analysed formalin-fixed paraffin-embedded (FFPE) and available subset of deep-frozen tissues (DFTs) of 102 L-SCC patients for the presence of all currently defined 51 mucosal HPV types, viral load, HPV mRNA expression and expression of cell cycle proteins $\mathrm{p} 16^{\mathrm{INK} 4 \mathrm{a}}$, pRb, cyclin D1 (CyD1) and p53, the cellular surrogate markers for HPV transformation. Applying this broad method spectrum on multiple patient biopsies, we provide biological evidence for causal involvement of HPV16 in a small fraction of L-SCC, and suggest a combination of markers to define HPV-driven L-SCC.

\section{MATERIALS AND METHODS}

Patients and tissue samples. This study was approved by the ethics committee of the Medical Faculty of the University of Heidelberg, study code 176/2002. A total of 102 L-SCC patients were enrolled. Patients were diagnosed with invasive L-SCC and treated at the ENT department of the University Hospital Heidelberg, Germany between 1990 and 2006. Patient's age ranged from 39 to 82, with a median of 59 years. An initial study inclusion criterion was the availability of at least one FFPE biopsy of a primary L-SCC tumour (P-TU). For 11 patients P-TU was not available, therefore tumour recurrence (TU-Rec) or L-SCC as a secondary carcinoma (2nd $\mathrm{Ca}$ ) were included. For 34 patients multiple FFPE biopsies (range 2-11; mean 4, median 3 FFPE biopsies pro-patient) were analysed. Owing to potential technical challenge imposed by formalin fixation in FFPE biopsies, we also analysed concordant DFT P-TU biopsies available for 55 patients (one DFT biopsy pro-patient). In total, 209 (154 FFPE and 55 DFT) biopsies were analysed for 102 patients; 91 patients had P-TU, 9 TU-Rec and 2 2nd Ca L-SCC. Per biopsy, tumour histology was independently verified by two study pathologists (CF and $\mathrm{BL}$ ). Per patient, clinical data were collected from clinical charts and pathological reports.

Tissue sectioning, DNA and RNA extraction. To probe the reproducibility of HPV DNA findings, each of 154 FFPE biopsies was sectioned twice and 308 DNA extracts were prepared. Deepfrozen tissue biopsies were sectioned once resulting in 55 DNA extracts. In total, 363 DNA extracts $(154 \times 2$ FFPE and 55 DFT) were analysed for 102 patients.

To prevent cross-contamination during sectioning, each biopsy (FFPE or DFT) was sectioned with a new blade, the sectioning area was cleaned with $70 \%$ ethanol and acetone, respectively, and gloves were changed accordingly. Each experimental step included necessary controls (Supplementary Information).

For nucleic-acid extractions, FFPE and DFT tissue ribbons were obtained according to the sandwich method, that is, the first and the last $4-\mu \mathrm{m}$-sections were stained by haematoxylin and eosin $(\mathrm{H} \& \mathrm{E})$ stain to verify the presence of tumour cells. The number of ribbons required for nucleic-acid extraction depended on the biopsy size. For FFPE, $2-8 \times 5 \mu \mathrm{m}$, and for DFT $2-8 \times 16 \mu \mathrm{m}$ tissue ribbons were cut, and genomic DNA was prepared as described (Halec et al, 2012; Holzinger et al, 2012). All DNA extracts were stored at $-20^{\circ} \mathrm{C}$ until use. Each FFPE and/or DFT biopsy that yielded HPV DNA + result was sectioned again to obtain tissue ribbons for RNA extraction. Total RNA was extracted as described (Halec et al, 2012; Holzinger et al, 2012). RNA samples were stored at $-80^{\circ} \mathrm{C}$ until use.

Human papilloma virus genotyping and measurement of HPV16 viral load. For genotyping $10 \mu \mathrm{l}$, and for HPV16 quantitative real-time PCR (qPCR) $1 \mu \mathrm{l}$, of DNA were used.

For HPV genotyping, broad-spectrum GP5 + $/ 6+$-PCR/multiplex HPV genotyping assay (BSGP5 + /6+-PCR/MPG) combining the BSGP5 + /6+-PCR, which homogeneously amplifies all 51 genital HPV types generating biotinylated amplimers of $\sim 150 \mathrm{bp}$ from the L1 region and $208 \mathrm{bp}$ amplicon of $\beta$-globin (Schmitt et al, 2008, 2013), and a Multiplex HPV Genotyping assay with beadbased xMAP Luminex suspension array technology (Qiagen, Hilden, Germany) (Schmitt et al, 2006, 2008) was used. An L-SCC case (including all biopsies from one patient) was considered valid if the $\beta$-globin and/or HPV DNA + was identified at least once. Each HPV DNA invalid (HPV and $\beta$ globin DNA - ) result was verified by retesting.

The qPCR assay targeting HPV16-specific sequences of the E6 gene was developed to calculate HPV16 viral genome copy-number per cell. Primer sequences used for $\mathrm{qPCR}$ are available upon request (Schmitt et al, manuscript in preparation). Quantitative real-time PCR for $\beta$-globin was used to verify the DNA quality and to measure the amount of input DNA. As on average, each tumour specimen contained $\sim 50 \%$ of tumour cells, and in HPVtransformed cells at least one genome copy per cell is expected, 0.5 copies of HPV16 genome per cell were set as a cut-off to define samples with high (HPV16 $6_{\text {high }} \geqslant 0.5$ copies per cell) or low (HPV16 low, $<0.5$ copies per cell) viral load (Holzinger et al, 2012).

E6 ${ }^{\star}$ I mRNA reverse transcription-PCR. One microlitre extracted RNA was subjected to a one-step reverse transcriptionPCR protocol with the QuantiTect Virus Kit (Qiagen, Hilden, Germany) using HPV type-specific primers to amplify cDNA 


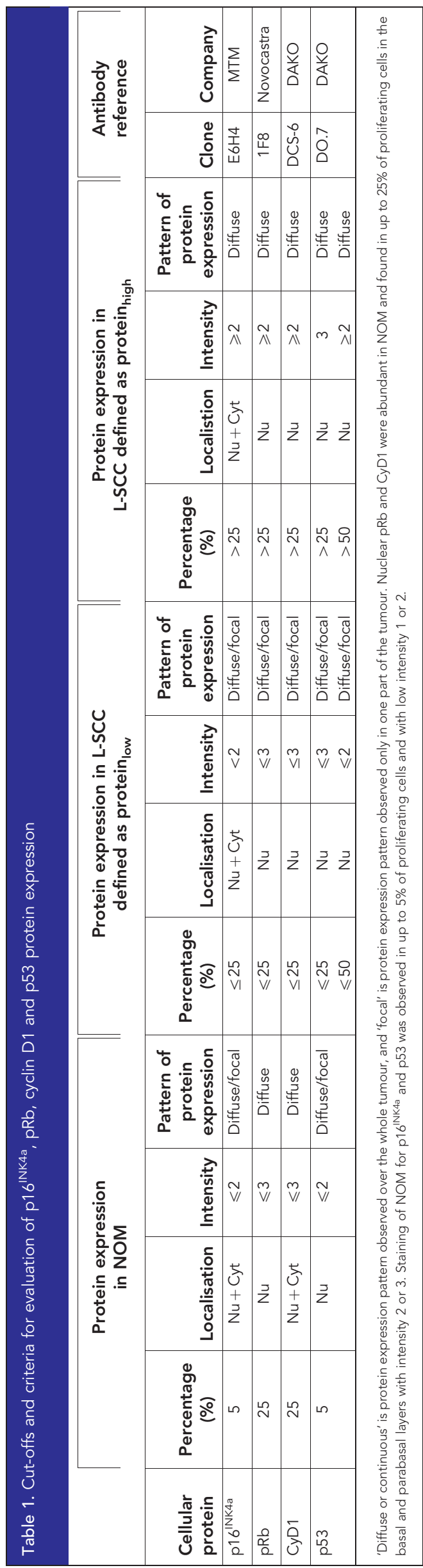

across the $6^{\star} \mathrm{I}$ splice site, as described (Halec et al, 2012). The biotinylated strands of the amplimers were detected by hybridisation with type- and splice site-specific oligonucleotide probes coupled to fluorescence-labelled Luminex beads (Luminex Corp., Austin, TX, USA). The E6 ${ }^{*}$ mRNA assays are available for 20 HR-/pHR-HPV types for which existence of splice sites was demonstrated ((Halec et al, 2012) and references therein), and applicable on both DFT and FFPE biopsies (Halec et al, 2012; Hoffmann et al, 2012). For detection of LR-HPV11 mRNA, the assay with primers designed to amplify $77 \mathrm{bp}$ amplicon of the full-length HPV11 E6 gene, and an oligonucleotide probe for HPV11 E6 full-length detection, was applied.

Immunohistochemical analysis on TMA. A tissue microarray (TMA) was constructed carrying the tissue cores obtained from FFPE biopsies of all 102 patients, and cores with normal oral mucosa (NOM) of a cancer-free patient as a staining control. Each L-SCC core was representative of the invasive tumour as assessed by $\mathrm{H} \& \mathrm{E}$ analysis from single sections. Tissue microarray slides were stained manually as described (Halec et al, 2012; Holzinger et al, 2013) and on DAKO autostainer (Glostrup, Denmark).Protein expressions were evaluated separately by four investigators (FXB, DHol, BL and GH). Evaluation involved semi-quantitative scoring of the staining intensity $(0=$ no expression, 1 or $2=$ low intensity and $3=$ high intensity) and the percentage of stained tumour cells, as described (Halec et al, 2012; Holzinger et al, 2013). For the simplicity of evaluation, only two protein expression categories were applied, low and high, with cut-off guided by protein expression in NOM. For $\mathrm{p} 16^{\mathrm{INK} 4 \mathrm{a}}$, $\mathrm{pRb}$ and CyD1, positivity in $>25 \%$ of the tumour cells with intensity $\geqslant 2$ was required to define high protein expression (Table 1). Evaluation of staining for p53 in association with HPV involvement was more complex. In HPV-driven carcinomas, p53 expression is initially upregulated by HPV E7 actions (Massimi and Banks, 1997), but HPV E6 counteracts this upregulation by targeting p53 for ubiquitinmediated degradation (Scheffner et al, 1990). However, wild-type p53 protein level can increase to immunohistochemical (IHC) detectable levels during, for example, cellular damage caused by HPV infection (Kastan et al, 1991; Gottlieb and Oren, 1996; Skyldberg et al, 2001). Therefore, we defined p53 expression as p $53_{\text {high }}$ when 553 positivity was found in $>50 \%$ of tumour cells with intensity $=2$, or in $>25$ of tumour cells with intensity $=3$.

Definition of HPV DNA +, HPV 16 high $_{\text {/HPV16 }}$ low $_{\text {low }}$ anddriven L-SCC. An L-SCC case (including all biopsies from one patient) was considered HPV DNA + if at least one DNA extract yielded HPV DNA + result.

To define HPV16 viral load per patient, DNA extract prepared from the first FFPE section, DNA extract prepared from the second, consecutive FFPE section of the same biopsy and DNA extract prepared from the DFT section results were combined. An L-SCC case was considered of high viral load $\left(\mathrm{HPV} 16_{\text {high }}\right.$ ) if quantitative results were above cut-off ( $\geqslant 0.5$ copies per cell) in $\geqslant 50 \%$ of findings.

Finally, based on CxCa and HPV-driven OP-SCC data (Halec et al, 2012; Holzinger et al, 2012) and data in this study, we defined combination of HPV DNA,$+ \mathrm{E}^{\star}{ }^{\star} \mathrm{I}$ mRNA + and high p16/low $\mathrm{pRb}\left(\mathrm{p} 16_{\text {high }} / \mathrm{pRb} \mathrm{b}_{\text {low }}\right)$ protein pattern in tumour cells as a critical parameter to define HPV-driven L-SCC. Detailed overview of HPV DNA, E6 ${ }^{\star} \mathrm{I}$ mRNA and IHC results per biopsy and per patient is provided in Supplementary Table S1.

\section{RESULTS}

Human papilloma virus DNA prevalence in L-SCC tissues. In this hospital series, 102 patients were included with their clinical characteristics, as described (Table 2). Altogether, 363 
Table 2. Clinical characteristics of patients stratified by HPV status

\begin{tabular}{|c|c|c|c|c|c|}
\hline & All $(\mathbf{N}=102)$ & DNA valid $(\mathbf{N}=92)^{a}$ & $\mathrm{HPV}^{-}(\mathbf{N}=60)$ & non-HPV driven $(N=28)^{b}$ & HPV driven $(\boldsymbol{N}=3)^{c}$ \\
\hline Characteristics & $\mathbf{N}(\%)$ & $\mathbf{N}(\%)$ & $\mathbf{N}(\%)$ & $\mathbf{N}(\%)$ & $\mathbf{N}(\%)$ \\
\hline \multicolumn{6}{|l|}{ Gender } \\
\hline $\begin{array}{l}\text { Male } \\
\text { Female }\end{array}$ & $\begin{array}{l}91(89) \\
11(11)\end{array}$ & $\begin{array}{l}81(88) \\
11(12)\end{array}$ & $\begin{array}{c}55(93) \\
4(7)\end{array}$ & $\begin{array}{r}24(86) \\
4(14)\end{array}$ & $\begin{array}{l}2(67) \\
1(33)\end{array}$ \\
\hline \multicolumn{6}{|l|}{ Age (years) } \\
\hline Median & 59.0 & 59.0 & 59.0 & 57.0 & 49.0 \\
\hline \multicolumn{6}{|l|}{ Localisation } \\
\hline $\begin{array}{l}\text { Supraglottic } \\
\text { Glottic } \\
\text { Subglottic }\end{array}$ & $\begin{array}{l}35(34) \\
65(64) \\
2(2)\end{array}$ & $\begin{array}{c}30(33) \\
60(65) \\
2(2)\end{array}$ & $\begin{array}{c}19(32) \\
39(65) \\
2(3)\end{array}$ & $\begin{array}{c}9(32) \\
19(68) \\
0(0)\end{array}$ & $\begin{array}{l}2(67) \\
1(33) \\
0(0)\end{array}$ \\
\hline \multicolumn{6}{|l|}{ Tumour status } \\
\hline $\begin{array}{l}\text { Primary } \\
\text { Recurrence } \\
\geqslant 2 \text { nd Ca }\end{array}$ & $\begin{array}{l}91(89) \\
9(9) \\
2(2) \\
\end{array}$ & $\begin{array}{c}81(88) \\
9(10) \\
2(2) \\
\end{array}$ & $\begin{array}{r}52(88) \\
5(8) \\
2(3) \\
\end{array}$ & $\begin{array}{c}23(82) \\
4(14) \\
1(4) \\
\end{array}$ & $\begin{array}{l}2(67) \\
1(33) \\
0(0)\end{array}$ \\
\hline \multicolumn{6}{|l|}{ Tumour size } \\
\hline $\begin{array}{l}\text { T1-T2 } \\
\text { T3-T4 } \\
\text { No data }\end{array}$ & $\begin{array}{c}38(42) \\
52(58) \\
12\end{array}$ & $\begin{array}{c}35(44) \\
45(56) \\
12\end{array}$ & $\begin{array}{c}22(40) \\
33(60) \\
5\end{array}$ & $\begin{array}{c}13(52) \\
12(48) \\
3\end{array}$ & $\begin{array}{c}1(50) \\
1(50) \\
1\end{array}$ \\
\hline \multicolumn{6}{|l|}{ Lymph nodes } \\
\hline $\begin{array}{l}\text { N0 } \\
\text { N1 }+ \\
\text { No data }\end{array}$ & $\begin{array}{c}64(73) \\
24(27) \\
14\end{array}$ & $\begin{array}{c}59(75) \\
20(25) \\
13\end{array}$ & $\begin{array}{c}46(82) \\
10(18) \\
3\end{array}$ & $\begin{array}{c}20(80) \\
5(20) \\
3\end{array}$ & $\begin{array}{l}2(100) \\
0(0) \\
1\end{array}$ \\
\hline \multicolumn{6}{|c|}{ Distant metastases } \\
\hline $\begin{array}{l}\text { M0 } \\
\text { M1 } \\
\text { No data }\end{array}$ & $\begin{array}{c}85 \text { (99) } \\
1(1) \\
12\end{array}$ & $\begin{array}{c}77(99) \\
1(1) \\
14\end{array}$ & $\begin{array}{c}55(100) \\
0(0) \\
4\end{array}$ & $\begin{array}{c}24(96) \\
1(3) \\
3\end{array}$ & $\begin{array}{l}2(100) \\
0(0) \\
1\end{array}$ \\
\hline \multicolumn{6}{|c|}{ Histopathological pattern } \\
\hline $\begin{array}{l}\text { Keratinising } \\
\text { Non-keratinising }\end{array}$ & $\begin{array}{c}98(96) \\
4(4)\end{array}$ & $\begin{array}{c}88(96) \\
4(4)\end{array}$ & $\begin{array}{c}59(98) \\
1(2)\end{array}$ & $\begin{array}{c}26(93) \\
2(7)\end{array}$ & $\begin{array}{l}2(67) \\
1(33)\end{array}$ \\
\hline \multicolumn{6}{|l|}{ Clinical stage } \\
\hline $\begin{array}{l}\text { I-III } \\
\text { IV } \\
\text { No data }\end{array}$ & $\begin{array}{c}43(53) \\
38(47) \\
21\end{array}$ & $\begin{array}{c}38(53) \\
34(47) \\
20\end{array}$ & $\begin{array}{c}15(29) \\
36(71) \\
8\end{array}$ & $\begin{array}{c}14(56) \\
11(44) \\
3\end{array}$ & $\begin{array}{c}1(50) \\
1(50) \\
1\end{array}$ \\
\hline \multicolumn{6}{|l|}{ Follow-up event } \\
\hline $\begin{array}{l}\text { Rec } \\
\text { 2nd Ca } \\
\text { Met } \\
\text { No event (censored) }\end{array}$ & $\begin{array}{l}16(16) \\
10(10) \\
17(16) \\
59(58)\end{array}$ & $\begin{array}{r}15(16) \\
9(10) \\
14(15) \\
54(59)\end{array}$ & $\begin{array}{r}6(10) \\
7(12) \\
12(20) \\
35(58)\end{array}$ & $\begin{array}{c}9(32) \\
1(4) \\
2(7) \\
16(57)\end{array}$ & $\begin{array}{l}0(0) \\
1(33) \\
0(0) \\
2(67)\end{array}$ \\
\hline \multicolumn{6}{|l|}{ Alcohol use } \\
\hline $\begin{array}{l}\text { Yes } \\
\text { No } \\
\text { Former } \\
\text { No data }\end{array}$ & $\begin{array}{l}65(79) \\
9(11) \\
8(10) \\
20 \\
\end{array}$ & $\begin{array}{l}57(78) \\
9(12) \\
7(10) \\
19 \\
\end{array}$ & $\begin{array}{r}37(77) \\
6(12) \\
5(10) \\
11 \\
\end{array}$ & $\begin{array}{l}18(82) \\
2(9) \\
2(9) \\
6\end{array}$ & $\begin{array}{c}1(50) \\
1(50) \\
0(0) \\
1\end{array}$ \\
\hline \multicolumn{6}{|l|}{ Tobacco use } \\
\hline $\begin{array}{l}\text { Yes } \\
\text { No } \\
\text { Former } \\
\text { No data }\end{array}$ & $\begin{array}{c}76(85) \\
5(6) \\
8(9) \\
13\end{array}$ & $\begin{array}{c}68(85) \\
5(6) \\
7(8) \\
12\end{array}$ & $\begin{array}{c}45(83) \\
5(9) \\
4(7) \\
5\end{array}$ & $\begin{array}{c}24(92) \\
0(0) \\
2(8) \\
2\end{array}$ & $\begin{array}{l}2(100) \\
0(0) \\
0(0) \\
1\end{array}$ \\
\hline
\end{tabular}


Table 2. (Continued)

\begin{tabular}{|c|c|c|c|c|c|}
\hline & All $(\mathbf{N}=102)$ & DNA valid $(\mathbf{N}=92)^{a}$ & $\mathrm{HPV}^{-}(\mathbf{N}=60)$ & non-HPV driven $(\boldsymbol{N}=28)^{\mathrm{b}}$ & HPV driven $(\mathbf{N}=3)^{c}$ \\
\hline Characteristics & $\mathbf{N}(\%)$ & $\mathbf{N}(\%)$ & $\mathbf{N}(\%)$ & $\mathbf{N}(\%)$ & $\mathbf{N}(\%)$ \\
\hline \multicolumn{6}{|c|}{ No of biopsies analysed } \\
\hline $\begin{array}{l}\text { FFPE } \\
\text { DFT }\end{array}$ & $\begin{array}{r}154(74) \\
55(26)\end{array}$ & $\begin{array}{r}144(72) \\
55(28)\end{array}$ & $\begin{array}{r}118(73) \\
44(27)\end{array}$ & $\begin{array}{r}22(71) \\
9(29)\end{array}$ & $\begin{array}{l}3(60) \\
2(40)\end{array}$ \\
\hline \multicolumn{6}{|c|}{$\begin{array}{l}\text { Abbreviations: DFT }=\text { deep-frozen tissue; FFPE }=\text { formalin-fixed paraffin-embedded. } \\
{ }^{a} \text { Number of patients with valid biopsies, that is, } \beta \text {-globin and/or HPV DNA-positive. } \\
\left.{ }^{b_{N}} \text { Number of patients with non-HPV-driven L-SCC ( } N=28\right) \text {. One patient (HPV16, } 45 \text { DNA }+ \text { ) was also HPV16 RNA }+ \text {; however, expression of proteins could not been assessed owing to poor } \\
\text { tissue quality for IHC analysis. Therefore that patient could not be grouped into }{ }^{b} \text { or }{ }^{c} \text {. } \\
{ }^{c} \text { The three HPV-driven L-SCC patients with HPV DNA +/RNA }+/ p 16 \text { high } / \text { pRblow pattern. }\end{array}$} \\
\hline
\end{tabular}

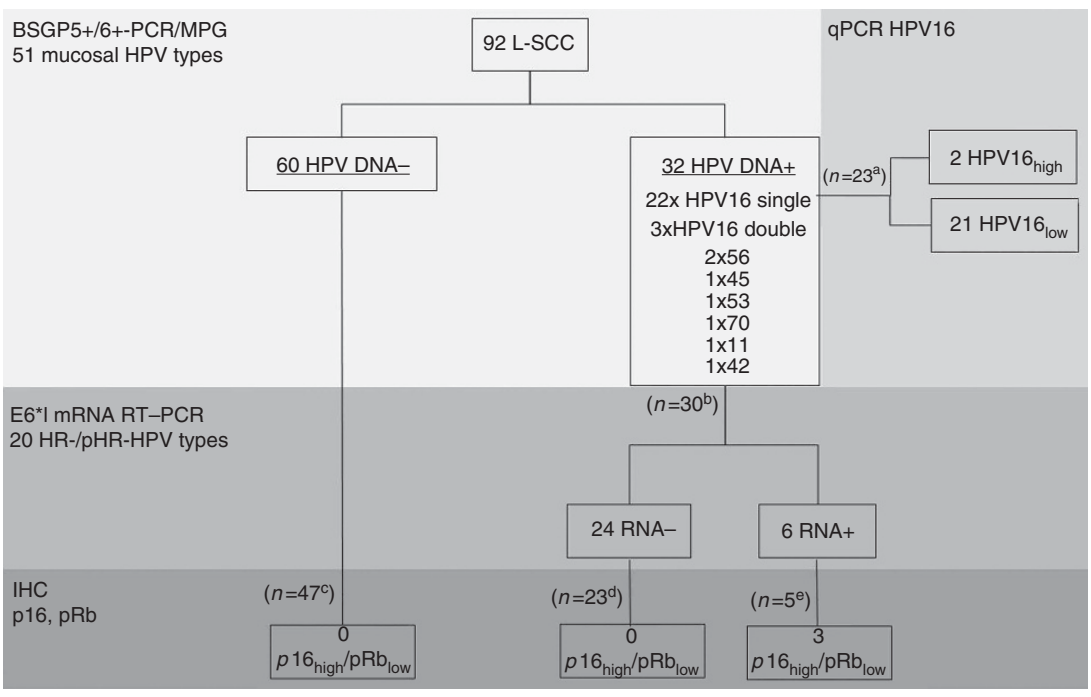

Figure 1. Study flow chart. Overall flow chart showing the grouping of L-SCC in relation to HPV DNA, viral load, E6*I mRNA expression and immunohistochemical (IHC) protein pattern defining HPV involvement as extrapolated from CxCa and OP-SCC. HPV16 high-high, HPV16 low-low HPV16 viral load as determined by HPV16 qPCR. ${ }^{a}$ For two samples, HPV16 viral load could not be quantified because of $\beta$-globin negativity in qPCR. ${ }^{b}$ For two samples RNA was not analysable, that is, both HPV RNA and ubiquitin C RNA were negative. ${ }^{c}$ For 13 patient cases defined as HPV DNA - , done RNA - and e one RNA + were of insufficient quality/quantity for IHC analysis. Combination of $\mathrm{p} 16_{\text {high }} / \mathrm{pR} \mathrm{b}_{\text {low }}$ expression was found in 3 HPV DNA + /RNA + tumours, but in none of the 23 HPV DNA + /RNA - or 47 HPV - tumours. This difference was statistically significant $\left(\chi^{2}-\right.$ test, $P=0.002$ and $P<.0001)$. These three tumours were defined as HPV-driven L-SCC.

DNA extracts $(154 \times 2$ FFPE and 55 DFT $)$ prepared from 209 tumour tissue samples (154 FFPE and 55 DFT) were analysed for the presence of all currently defined 51 mucosal HPV types.

At least one valid DNA sample (HPV and/or $\beta$-globin DNA + ) was obtained from 80 of the 102 patients $(78 \%)$ with FFPE tissues and from all of the 55 patients with additionally DFT biopsy available, including 12 patients with no valid FFPE-derived sample (Figure 1). Ten patients with FFPE biopsies only, were DNA invalid and excluded from the analysis. Of the 92 L-SCC patients with at least one valid DNA sample, 32 (35\%) were HPV DNA +, with a single HPV type found in 29 (91\%) and multiple types found in 3 (9\%) cases (Table 3). Human papilloma virus DNA positivity in present L-SCC series did not significantly change over the sampling period, with $30 \%$ in the first half of cases collected until 1997 and 24\% in the second half of cases collected thereafter.

HPV type 16 was the most prevalent type found in 22 out of 29 (76\%) single, and in all 3 multiple-type positive cases. High-risk-/ pHR-HPV types 45,53 and 70 were identified as single sequences in one case each and HPV56 in two cases. Two L-SCC cases harboured LR-HPV type 11 and 42, respectively. The three cases with multiple HPV types harboured HPV16 together with HPV33 (two cases) and HPV45 (one case).

Of 23 patients with at least one HPV DNA + FFPE-derived DNA sample, and a valid, second FFPE-derived DNA sample, the same HPV type was found in only $6(26 \%)$ of the second DNA samples. Among 16 valid DNA sample pairs derived from FFPE/ DFT tissue pairs with at least one HPV DNA + sample, only 5 (31\%) had concordantly positive DNA samples. In total, for only $10(32 \%)$ of 31 patients with at least one HPV DNA + sample, the DNA findings could be reproduced in a second DNA sample (Table 3, Supplementary Table S1).

In viral load analysis, 13 of the $25 \mathrm{HPV} 16 \mathrm{DNA}+$ samples were HPV16 DNA - , 8 had viral loads $<0.5$ copies per cell, 2 had viral loads $>0.5$ copies per cell and for 2 HPV16 viral loads could not be calculated (non-quantifiable) because of $\beta$-globin negativity. Thus, of the 23 HPV16 DNA + tumours analysable by qPCR, 2 (9\%) were defined as HPV16 high and 21 (91\%) as HPV16 low (Table 3, Figure 1).

Interestingly, both HPV16 ${ }_{\text {high }}$ L-SCC cases had reproducible HPV DNA + findings from the consecutive FFPE section and/or DFT biopsies (Table 3). However, only 5 out of 21 (24\%) 


\begin{tabular}{|c|c|c|c|c|c|c|c|c|c|c|}
\hline $\begin{array}{l}\text { Patient } \\
\text { number }\end{array}$ & $\begin{array}{l}\text { Tissue } \\
\text { biopsy }\end{array}$ & $\begin{array}{l}\text { HPV } \\
\text { DNA }\end{array}$ & $\begin{array}{l}\text { HPV16 DNA } \\
\text { copies/cell }\end{array}$ & $\begin{array}{c}\text { Final HPV } \\
\text { DNA and VL }\end{array}$ & $\begin{array}{l}\text { HPV } \\
\text { RNA }\end{array}$ & p16 high & $p R b_{\text {low }}$ & CyD1 $1_{\text {low }}$ & p53 low & $\begin{array}{l}\text { HPV-driven } \\
\text { L-SCC }\end{array}$ \\
\hline 1 & $\begin{array}{c}\text { FFPE }_{1} \\
\text { FFPE }_{2} \\
\text { DFT }\end{array}$ & $\begin{array}{l}16 \\
16 \\
16\end{array}$ & $\begin{array}{c}6769 \\
\text { Invalid } \\
227\end{array}$ & $16 \mathrm{H}$ & 16 & + & + & + & + & + \\
\hline 2 & $\begin{array}{c}\text { FFPE }_{1} \\
\text { FFPE }_{2} \\
\text { DFT }\end{array}$ & $\begin{array}{l}16 \\
16\end{array}$ & $\begin{array}{l}15 \\
18\end{array}$ & $16 \mathrm{H}$ & 16 & + & + & - & + & + \\
\hline 3 & $\begin{array}{c}\text { FFPE }_{1} \\
\text { FFPE }_{2} \\
\text { DFT }\end{array}$ & $\begin{array}{c}\text { Invalid } \\
\text { Invalid } \\
16\end{array}$ & $\begin{array}{l}\text { Invalid } \\
\text { Invalid } \\
<0.001\end{array}$ & $16 \mathrm{~L}$ & 16 & + & + & + & + & + \\
\hline 4 & $\begin{array}{c}\text { FFPE }_{1} \\
\text { FFPE }_{2} \\
\text { DFT }\end{array}$ & $\begin{array}{l}- \\
16 \\
16\end{array}$ & $\begin{array}{c}0.07 \\
0.004\end{array}$ & $16 \mathrm{~L}$ & - & - & + & - & + & - \\
\hline 5 & $\begin{array}{c}\text { FFPE }_{1} \\
\text { FFPE }_{2} \\
\text { DFT }\end{array}$ & $\begin{array}{c}\text { Invalid } \\
16 \\
16\end{array}$ & $\begin{array}{l}0 \\
0 \\
0\end{array}$ & $16 \mathrm{~L}$ & - & - & - & + & + & - \\
\hline 6 & $\begin{array}{c}\text { FFPE }_{1} \\
\text { FFPE }_{2} \\
\text { DFT }\end{array}$ & $\begin{array}{c}16 \\
\text { Invalid } \\
16\end{array}$ & $\begin{array}{c}0 \\
0 \\
<0.001\end{array}$ & $16 \mathrm{~L}$ & - & NA & NA & NA & NA & - \\
\hline 7 & $\begin{array}{c}\text { FFPE }_{1} \\
\text { FFPE }_{2} \\
\text { DFT }\end{array}$ & $\begin{array}{c}16 \\
\text { Invalid } \\
16\end{array}$ & $\begin{array}{c}0 \\
0 \\
<0.001\end{array}$ & $16 \mathrm{~L}$ & - & - & + & - & + & - \\
\hline 8 & $\begin{array}{c}\text { FFPE }_{1} \\
\text { FFPE }_{2} \\
\text { DFT }\end{array}$ & $\begin{array}{l}16 \\
- \\
-\end{array}$ & 0 & $16 \mathrm{~L}$ & - & - & - & + & + & - \\
\hline 9 & $\begin{array}{c}\text { FFPE }_{1} \\
\text { FFPE }_{2} \\
\text { DFT }\end{array}$ & $\begin{array}{l}- \\
16 \\
-\end{array}$ & 0 & $16 \mathrm{~L}$ & - & - & - & + & - & - \\
\hline 10 & $\begin{array}{c}\text { FFPE }_{1} \\
\text { FFPE }_{2} \\
\text { DFT }\end{array}$ & $\begin{array}{c}16 \\
\text { Invalid } \\
-\end{array}$ & $\begin{array}{l}0 \\
0\end{array}$ & $16 \mathrm{~L}$ & - & - & - & - & - & - \\
\hline 11 & $\begin{array}{c}\text { FFPE }_{1} \\
\text { FFPE }_{2} \\
\text { DFT }\end{array}$ & $\begin{array}{c}\text { Invalid } \\
- \\
16\end{array}$ & $\begin{array}{c}0 \\
<0.001\end{array}$ & $16 \mathrm{~L}$ & - & - & - & + & - & - \\
\hline 12 & $\begin{array}{c}\text { FFPE }_{1} \\
\text { FFPE }_{2} \\
\text { DFT }\end{array}$ & $\begin{array}{l}- \\
- \\
16\end{array}$ & 0 & $16 \mathrm{~L}$ & - & - & + & - & + & - \\
\hline 13 & $\begin{array}{c}\text { FFPE }_{1} \\
\text { FFPE }_{2} \\
\text { DFT }\end{array}$ & $\begin{array}{l}- \\
- \\
16\end{array}$ & 0 & $16 \mathrm{~L}$ & 16 & - & - & - & - & - \\
\hline 14 & $\begin{array}{c}\text { FFPE }_{1} \\
\text { FFPE }_{2} \\
\text { DFT }\end{array}$ & $\begin{array}{l}- \\
- \\
16\end{array}$ & 0 & $16 \mathrm{~L}$ & - & - & + & + & + & - \\
\hline 15 & $\begin{array}{c}\text { FFPE }_{1} \\
\text { FFPE }_{2} \\
\text { DFT }\end{array}$ & $\begin{array}{l}- \\
- \\
16\end{array}$ & $<0.001$ & $16 \mathrm{~L}$ & - & - & + & - & + & - \\
\hline 16 & $\begin{array}{c}\text { FFPE }_{1} \\
\text { FFPE }_{2} \\
\text { DFT }\end{array}$ & $\begin{array}{l}16 \\
16\end{array}$ & $\begin{array}{c}\mathrm{NQ} \\
\text { Invalid }\end{array}$ & $16 \mathrm{~L}$ & - & - & - & + & + & - \\
\hline 17 & $\begin{array}{c}\text { FFPE }_{1} \\
\text { FFPE }_{2} \\
\text { DFT }\end{array}$ & $\begin{array}{l}16 \\
-\end{array}$ & 0 & $16 \mathrm{~L}$ & - & - & - & - & + & - \\
\hline 18 & $\begin{array}{c}\text { FFPE }_{1} \\
\text { FFPE }_{2} \\
\text { DFT }\end{array}$ & $\begin{array}{l}16 \\
-\end{array}$ & 0 & $16 \mathrm{~L}$ & - & - & - & - & + & - \\
\hline 19 & $\begin{array}{c}\text { FFPE }_{1} \\
\text { FFPE }_{2} \\
\text { DFT }\end{array}$ & $\begin{array}{l}16 \\
16\end{array}$ & $\begin{array}{c}<0.001 \\
0\end{array}$ & $16 \mathrm{~L}$ & - & - & - & + & + & - \\
\hline 20 & $\begin{array}{c}\text { FFPE }_{1} \\
\text { FFPE }_{2} \\
\text { DFT }\end{array}$ & $\begin{array}{l}16 \\
-\end{array}$ & 0 & $16 \mathrm{~L}$ & - & - & - & - & - & - \\
\hline
\end{tabular}




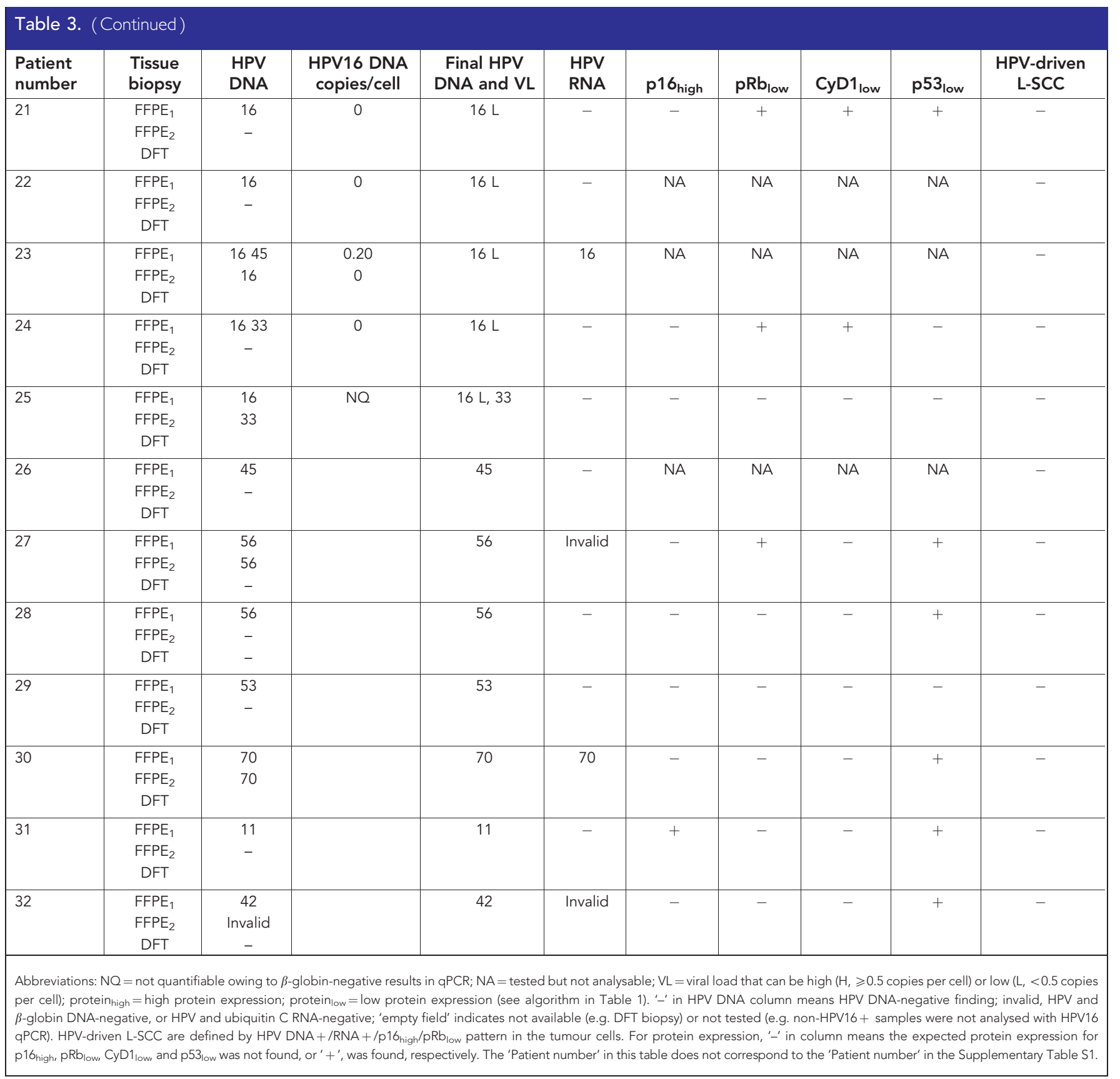

HPV16 $6_{\text {low }}$ L-SCC cases had reproducible HPV DNA + results supporting the HPV16 $6_{\text {low }}$ findings.

HPV E6 ${ }^{\star} I$ mRNA expression in HPV DNA + L-SCC. E6 ${ }^{\star} I$ mRNA was found in 6 out of 30 (20\%) RNA analysable cases; 5 of them were found harbouring single HPV16 and one HPV70 (Table 3). Among the five HPV16 RNA + cases, viral load was high in two (40\%) cases (18 and 6800 genome copies per cell, respectively) and low in three (60\%) other cases (with $0.20,0.0001$ and non-quantifiable copies per cell, respectively, Table 3). Among all 18 RNA - cases analysable by HPV16 qPCR, viral load was low including 9 (45\%) non-quantifiable HPV16 DNA + samples. This difference was statistically significantly $\left(\chi^{2}\right.$-test, $\left.P=0.005\right)$.

P16 ${ }^{\text {INK4a }}, \mathrm{pRb}, \mathrm{CyD1}$ and p53 protein expression in L-SCC. Expression levels of $\mathrm{p} 16^{\mathrm{INK} 4 \mathrm{a}}$ and $\mathrm{pRb}$ proteins could be analysed for 75, and CyD1 and p53 for 65 and 69 patients, respectively.
High expression of $\mathrm{p} 16^{\mathrm{INK} 4 \mathrm{a}}\left(\mathrm{p} 16_{\text {high }}\right.$ ) was found in 4 out of 75 (5\%) cases, 3 of them were HPV16 DNA + and RNA + and the one remaining case was HPV11 DNA + but RNA - . Thus, three of the five RNA + cases (60\%) analysable by IHC were p16 high, and this was statistically significantly different from HPV RNA and HPV DNA - groups, where only one out of 21 (5\%, $\chi^{2}$-test, $P=0.002)$ and none of $47\left(\chi^{2}\right.$-test, $\left.P<0.0001\right)$ showed p16 high. The specificity of $\mathrm{p} 16_{\text {high }}$ for HPV RNA + group was even higher for HPV16 RNA + cases only, that is, when HPV70 RNA + case was excluded (75\% vs $60 \%$, Table 4$)$.

Low $\mathrm{pRb}$ expression $\left(\mathrm{pRb}_{\text {low }}\right.$ ) was found in 33 out of 75 (44\%) cases. Of the 5 HPV RNA + , IHC analysable cases, 3 (60\%) were $\mathrm{pRb}_{\text {low }}$, compared with 8 out of $21(38 \%)$ HPV RNA - and 22 out of $47(47 \%)$ HPV DNA - cases with $\mathrm{pRb}_{\text {low. However, this }}$ difference was not statistically significant $\left(\chi^{2}\right.$-test, $\left.P=0.373\right)$.

Low CyD1 expression $\left(\mathrm{CyD} 1_{\text {low }}\right)$ was found in 33 out of 65 $(51 \%)$ cases. Of the 5 RNA + L-SCC, $2(40 \%)$ were $C y D 1_{\text {low }}$, 


\begin{tabular}{|c|c|c|c|c|c|c|c|}
\hline & $\begin{array}{c}\text { L-SCC }_{\text {HPV DNA - }} \\
(\mathbf{N}=35) \\
\end{array}$ & $\begin{array}{l}\text { L-SCC }{ }_{\mathrm{HPV} 16} \\
\text { DNA + RNA - } \\
(\mathbf{N}=18)\end{array}$ & $\begin{array}{c}\text { L-SCC }_{\text {HPV16 RNA }+} \\
(\mathbf{N}=4) \\
\end{array}$ & $\begin{array}{l}\text { OP-SCC } \\
(\mathbf{N}=93)^{\mathrm{a}} \\
\end{array}$ & $\begin{array}{c}\text { OP-SCC }_{\text {HPV16 }} \\
\text { DNA }+ \text { RNA - } \\
(\mathbf{N}=\mathbf{5 5})^{\mathrm{a}}\end{array}$ & $\begin{array}{c}\text { OP-SCC } \text { HPV16 } \\
\text { RNA }+ \\
(\mathbf{N}=\mathbf{4 0})^{a} \\
\end{array}$ & $\begin{array}{l}\text { CxCa } \\
\quad(\mathbf{N}=44)^{\mathrm{b}}\end{array}$ \\
\hline $\begin{array}{l}\text { Cellular protein } \\
\text { expression levels }\end{array}$ & $\mathbf{N}(\%)$ & $\mathbf{N}(\%)$ & $\mathbf{N}(\%)$ & (\%) & (\%) & (\%) & (\%) \\
\hline \multicolumn{8}{|l|}{$p 16^{\text {INK4a }}$} \\
\hline $\begin{array}{l}\text { High } \\
\text { Low }\end{array}$ & $\begin{array}{c}0 \\
35(100)\end{array}$ & $\begin{array}{c}0 \\
18(100)\end{array}$ & $\begin{array}{l}3(75) \\
1(25)\end{array}$ & $\begin{array}{l}(14) \\
(86)\end{array}$ & $\begin{array}{l}(21) \\
(79)\end{array}$ & $\begin{array}{l}(80) \\
(20)\end{array}$ & $\begin{array}{l}(98) \\
(2)\end{array}$ \\
\hline \multicolumn{8}{|l|}{$\mathrm{pRb}$} \\
\hline $\begin{array}{l}\text { High } \\
\text { Low }\end{array}$ & $\begin{array}{l}19(54) \\
16(46)\end{array}$ & $\begin{array}{r}11(61) \\
7(39)\end{array}$ & $\begin{array}{l}1(25) \\
3(75)\end{array}$ & $\begin{array}{l}(89) \\
(11)\end{array}$ & $\begin{array}{l}(82) \\
(18)\end{array}$ & $\begin{array}{l}(15) \\
(85)\end{array}$ & $\begin{array}{l}(5) \\
(95)\end{array}$ \\
\hline \multicolumn{8}{|l|}{ CyD1 } \\
\hline $\begin{array}{l}\text { High } \\
\text { Low }\end{array}$ & $\begin{array}{l}15(43) \\
20(57)\end{array}$ & $\begin{array}{l}9(50) \\
9(50)\end{array}$ & $\begin{array}{l}2(50) \\
2(50)\end{array}$ & $\begin{array}{l}(56) \\
(44)\end{array}$ & $\begin{array}{l}(54) \\
(46)\end{array}$ & $\begin{array}{l}\text { (5) } \\
(95)\end{array}$ & $\begin{array}{l}(21)^{c} \\
(79)^{c}\end{array}$ \\
\hline \multicolumn{8}{|l|}{ p53 } \\
\hline $\begin{array}{l}\text { High } \\
\text { Low }\end{array}$ & $\begin{array}{r}8(23) \\
27(77)\end{array}$ & $\begin{array}{r}6(33) \\
12(67)\end{array}$ & $\begin{array}{l}1(25) \\
3(75)\end{array}$ & $\begin{array}{l}(49) \\
(51)\end{array}$ & $\begin{array}{l}(62) \\
(38)\end{array}$ & $\begin{array}{l}(15) \\
(85)\end{array}$ & $\begin{array}{l}(39) \\
(61)\end{array}$ \\
\hline $\mathrm{p} 16_{\text {high }} / \mathrm{pR} \mathrm{b}_{\text {low }}$ & 0 & 0 & $3(75)$ & (5) & (8) & (80) & (95) \\
\hline Other & 35 (100) & $18(100)$ & $1(25)$ & (95) & (92) & (20) & (5) \\
\hline 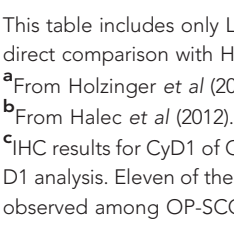 & $\begin{array}{l}\text { SCC with analysable It } \\
\text { PV16 DNA+ OP-SCC } \\
\text { 13). } \\
\text { Importantly, the prote } \\
\text { xCa series published ir } \\
\text { e } 14 \text { (79\%) showed CyL } \\
\text { HPV DNA- and OP-SCC }\end{array}$ & $\begin{array}{l}\text { data for all four pr } \\
\text { d CxCa, respective } \\
\text { expression in Holzir } \\
\text { Halec et al (2012) are } \\
\text { low expression. Expr } \\
\text { PV16 DNA+ RNA - grc }\end{array}$ & $\begin{array}{l}\text { teins (35 of } 60 \text { HPV DNA } \\
\text { ger et al (2013) and Halec } \\
\text { eported here for the first } t \\
\text { ssion of all four proteins w } \\
\text { ups (Holzinger et al, 2013) }\end{array}$ & $\begin{array}{l}\text { - and } 22 \text { of } 25 \text { HPV16 DN } \\
\text { et al (2012) was assessed } \\
\text { time. Only a small fraction, } \\
\text { vas similar across L-SCC } \mathrm{HPV} \\
\text { ). }\end{array}$ & $\begin{array}{l}\text { A+ L-SCC). Non-HP } \\
\text { using the same antib } \\
14 \text { of } 44 \text { HPV16 RNA } \\
\text { DNA - and L-SCCHPV }\end{array}$ & $\begin{array}{l}16 \text { DNA + cases are } \\
\text { dy references and ev } \\
\text { CxCa, had enough t } \\
\text { DNA+ RNA - groups. }\end{array}$ & $\begin{array}{l}\text { not included for better } \\
\text { evaluation criteria. } \\
\text { tissue material for cyclin } \\
\text { Such similarity was also }\end{array}$ \\
\hline
\end{tabular}

compared with 9 out of 21 (43\%) HPV RNA - and 22 out of 37 (59\%) HPV DNA - cases with CyD $1_{\text {low. }}$.

Low p53 expression (p53 low $)$ was found in 53 out of $69(77 \%)$ cases. Low p53 expression did not differ significantly between HPV status groups with 4 out of 5 (80\%) HPV RNA +, 14 out of 21 (67\%) HPV RNA - and 33 out of 41 (80\%) HPV DNA - cases.

The two cases non analysable for HPV RNA (HPV42 and one of the two HPV56 DNA + cases) showed p16 low $, \mathrm{pRb} b_{\text {high }}, \mathrm{CyD} 1_{\text {high }}$ and $\mathrm{p} 53_{\text {low }}$ expressions, respectively.

The marker combination $\mathrm{p} 16_{\text {high }} / \mathrm{pR} b_{\text {low }}$, indicative of viral transformation, was found in none of the $47 \mathrm{HPV}$ DNA - or the 21 HPV RNA - tumours, but in 3 out of $5(60 \%)$ of the HPV $\mathrm{RNA}+$ tumours analysable by IHC $\left(\chi^{2}\right.$-test $P<0.0001$ each). This difference was even higher when only HPV16 RNA + L-SCC were selected (75\% vs $60 \%$, Table 4$)$. These three tumours with HPV16 $\mathrm{RNA}+$ and $\mathrm{p} 16_{\text {high }} / \mathrm{pRb}$ low IHC pattern (hereafter referred as HPV-driven tumours) showed $\mathrm{p} 53_{\text {low }}$ in each case, whereas $\mathrm{CyD} 1_{\text {low }}$ and high HPV16 load were found in two cases, respectively. Please see Figure 2 for the examples of IHC staining.

Clinical characteristics of L-SCC patients and histopathological tumour patterns according to the HPV status. Patients with HPV DNA - $(N=60)$, and with HPV DNA + or RNA + tumours defined as non-HPV driven $(N=28)$ did not show statistically significant differences considering gender, tumour localisation, tumour status or size, development of lymph node/ distant metastases, or TU-Rec/secondary tumour/any metastasis, or alcohol drinking and smoking habits (Table $2, \chi^{2}$-test, $P>0.05$ ). The differences in clinicopathological features among the $3 \mathrm{HPV}$ driven, compared with the 28 non-HPV-driven or $60 \mathrm{HPV}$ DNA - patients could not be statistically assessed owing to the small sample numbers in HPV-driven group. Interestingly, the median age of the three HPV-driven patients was 8 years lower than of those in the non-HPV-driven group, and 10 years lower than in the HPV DNA - group.

Pathological review of the 102 cases revealed 98 (96\%) keratinising and $4(4 \%)$ non-keratinising tumours, of which 1 was HPV DNA - and 3 were HPV DNA + (one HPV16 DNA + / RNA - , one HPV11 DNA + /RNA - and one HPV16-driven; (Table 2). These observations, also based on small numbers, do not indicate that HPV-driven laryngeal SCC are preferentially nonkeratinising, as has been observed for the oropharynx (El-Mofty and Patil, 2006; Chernock et al, 2009).

\section{DISCUSSION}

The biological role of HPV in the pathogenesis of L-SCC as compared with OP-SCC has not been sufficiently defined. Many studies in $\mathrm{CxCa}$ and its precursors have established individual markers of HPV transformation (Klaes et al, 2001; Tsuda et al, 2003; Sotlar et al, 2004; Schmitt et al, 2010), and recently marker combinations have been comprehensively analysed in $\mathrm{CxCa}$ as a basis for stringent definition of HPV-driven mucosal cancers (Halec et al, 2012). Such marker combinations have also been useful in OP-SCC to discriminate HPV-driven from non-HPVdriven tumours with or without HPV DNA (Smeets et al, 2007; Jung et al, 2010; Holzinger et al, 2012; Liang et al, 2012).

We thoroughly analysed both FFPE and fresh, frozen tumour biopsies of 102 L-SCC patients for HPV presence and markers of biological activity. Using a stringent definition, we considered 


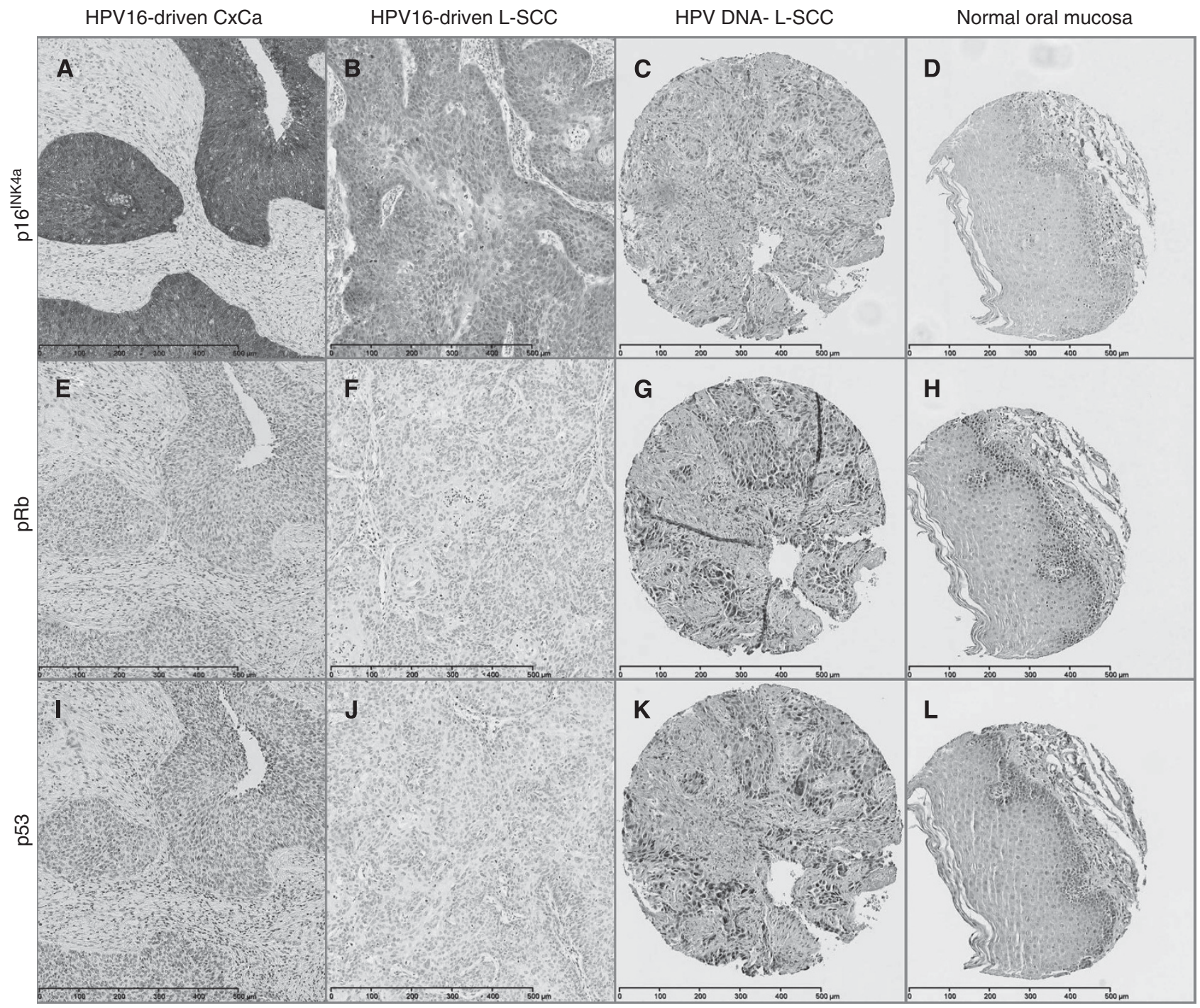

Figure 2. Examples of IHC staining for p16 ${ }^{\mathrm{INK} 4 a}, \mathrm{pRb}$ and $\mathrm{p} 53$ in $\mathrm{CxCa}, \mathrm{L}-\mathrm{SCC}$ and NOM, respectively. HPV16-driven CxCa (FFPE section, (A) p16 high, (E) pRb low, (I) p53 low); HPV16-driven L-SCC (FFPE section, (B) p16 high, (F) pRb low, (J) p53 low); HPV DNA - L-SCC (FFPE core on TMA, (C)

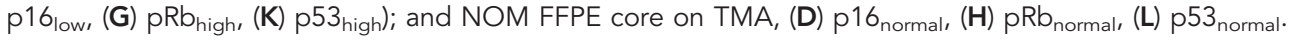

L-SCC cases as HPV-driven only when a marker combination with $\mathrm{HPV}$ DNA $+/ \mathrm{RNA}+/ \mathrm{p} 16_{\text {high }} / \mathrm{pRb}$ low was identified. Among the 73 cases with valid DNA, IHC and RNA (HPV DNA + only) data, we identified only 3 (4\%) fulfilling this definition, all 3 harbouring HPV16 as a single infection.

We did not consider the presence of viral transcripts per se as a sufficient marker for HPV transformation. In the cervix, HPV16 E6 ${ }^{\star}$ I transcripts are also abundantly expressed in infection without transformation (Schmitt et al, 2010); therefore, it is a marker of biological activity but is not transformation specific. Further, HPV16 DNA + oropharyngeal SCC with HPV16 E6*I transcription have been identified that, however, did not display cellular transformation markers and also did not show the better survival typically associated with HPV-driven OP-SCC (Holzinger et al, 2012). Upregulation of $\mathrm{p} 16^{\mathrm{INK} 4 \mathrm{a}}$ and downregulation of $\mathrm{pRb}$ are well established and frequent cellular consequences of HPV transformation, and were added here for a stringent definition of HPV-driven tumours.

In this series, there was no case positive for two functional markers, and 12 cases were positive for one functional marker only (nine $\mathrm{DNA}+/ \mathrm{pRb}_{\text {low }}$, two $\mathrm{DNA}+/ \mathrm{RNA}+$ and one $\mathrm{DNA}+/$ $\left.\mathrm{p} 16_{\text {high }}\right)$. These data indicate a robust separation of truly
HPV-driven L-SCC $v s$ HPV DNA + cases in which the additional markers did not support the classification as HPV-driven tumours.

Among the 29 cases lacking either valid DNA, RNA or IHC data, 2 were $\mathrm{p} 16_{\text {high }} / \mathrm{pRb}$ low $(\mathrm{DNA}$ invalid, Supplementary Table 1) and 1 was HPV16 RNA + (IHC invalid), representing at maximum three more candidates for HPV-driven L-SCC cases in this series.

Reproducibility of HPV DNA + and HPV16 viral load supported our stringent definition of HPV-driven L-SCC. Among cases with multiple valid tissue sections, only $29 \%$ of non-HPVdriven but two of the two HPV-driven cases had reproducible HPV DNA + findings. Also, all non-HPV-driven HPV16 DNA + tumours showed viral loads far below 0.5 genome copies per cell, whereas two of the three HPV-driven L-SCC showed high viral loads with 6800 and 18 HPV16 genome copies per cell. The low viral load in the third HPV-driven case remains unexplained.

Taken together, of the $102 \mathrm{~L}-\mathrm{SCC}$ cases that at least had valid DNA or IHC data, a minimum of $3(3 \%)$ with potentially a maximum of $6(6 \%)$ appear to be HPV driven. This small fraction of HPV-driven tumours in L-SCC is in line with three previous studies that demonstrated HPV16 DNA + /RNA + $/ \mathrm{p} 16_{\text {high }}$ in 2 of 27 (7\%; Schlecht et al, 2011), 1 of 30 (3\%) (Lewis et al, 2012) and in 
3 of 60 (5\%) L-SCC cases (Chernock et al, 2012). These data demonstrate that HPV16-driven L-SCC do exist but contribute only little to the overall L-SCC burden.

Ascertainment of the HPV-driven tumours as laryngeal and exclusion of any potentially oropharyngeal origin is crucial. The three HPV-driven tumours were clinically classified as primary laryngeal tumours without clinical evidence of OP extension. They were surgically removed in toto allowing pathological analysis of the tumour borders. One of the HPV-driven supraglottic tumours had cartilage, and the second supraglottic tumour had respiratory epithelium evident on H\&E slides. The third HPV-driven tumour was a big glottic tumour extending also into supraglottis and subglottis, but importantly, again with no border extending into hypopharynx or base of the tongue.

The overall HPV DNA prevalence in our study was 35\%, with HPV16 being the predominant genotype. This is comparable with previous studies from Central Europe where overall HPV DNA prevalence in L-SCC collected mainly between 1990 and 2006 varied between 20 and 35\% (Salam et al, 1995; Gorgoulis et al, 1999; Morshed et al, 2008). Although HPV DNA positivity in L-SCC tissue samples is substantial, our data demonstrate that in most (around 90\%) of these cases HPV is not the driving force. This separates L-SCC from OP-SCC in Central Europe where HPV prevalences of 15-50\% were reported (Smeets et al, 2007; Smith et al, 2008; Jung et al, 2010; Holzinger et al, 2012), and HPV has an aetiological role in $\sim 45 \%$ of HPV DNA + OP-SCC tumours (Smeets et al, 2007; Jung et al, 2010; Holzinger et al, 2012).

Human papilloma virus DNA positivity in non-HPV-driven tumour biopsies could at least theoretically originate from the cross-contamination in routine pathological tissue processing or from laboratory contaminations. The similar HPV DNA prevalence in DFT-derived samples that had not gone through routine pathological tissue processing, when compared with FFPE tissues, and utmost care we applied to avoid and to detect any laboratory contaminations, appear to argue against such contamination hypothesis. Human papilloma virus DNA positivity could also result from non-transforming infection in tumour or neighbouring tissue, or may represent depositions of material from oral HPV infection at other sites.

The relative fraction of HPV DNA + OP-SCC or tonsillar cancers appears to have increased in the last decades in the United States and Europe (D'Souza and Dempsey, 2011). In our L-SCC case series, HPV DNA positivity did not significantly change with tumour collection time, and all three HPV16-driven and the three potentially HPV-driven L-SCC in our series were among the first half of tumours to be collected.

The BSGP5 + $6+-$-PCR/MPG assay identifies all currently defined 51 mucosal HPV types, which allowed us to address the question whether presence of other HPV types in L-SCC may have been overlooked in the past. Besides HPV16 in 25 cases, we detected 3 HR- (HPV33, 45 and 56), 2 pHR- (HPV53 and 70) and 2 LR-HPV (HPV11 and 42) types as single or co-sequences in 10 cases. Eight of these cases showed no other marker for an HPVdriven tumour. One HPV70 DNA + case was HPV70 E6*I mRNA + but the $\mathrm{p} 16_{\text {low }} / \mathrm{pRb}$ high $/ \mathrm{CyD} 1_{\text {high }}$ IHC pattern argued against a transforming role of HPV70. One HPV11 DNA + case had a high $\mathrm{p} 16^{\mathrm{INK} 4 \mathrm{a}}$ expression, but also $\mathrm{pRb} \mathrm{b}_{\text {high }} / \mathrm{CyD} 1_{\text {high }}$ and HPV11 RNA was not detectable. These data indicate that mucosal HPV types other than HPV16 do not contribute significantly to L-SCC development. This is in accordance with the data from (Chernock et al, 2012) who detected 3 HPV16 RNA + /p16 $6_{\text {high }}$ and 1 HPV31 RNA +/p16 $6_{\text {high }}$ L-SCC among the 60 cases tested.

We performed IHC analyses for four protein markers that are targeted directly (pRb and p53) or indirectly (p16 ${ }^{\mathrm{INK} 4 \mathrm{a}}$ and $\mathrm{CyD} 1)$ by $\mathrm{HPV}$ in $\mathrm{CxCa}$. The $\mathrm{p} 16_{\text {high }} / \mathrm{pRb}$ low $\mathrm{IHC}$ marker combination required for our definition of HPV-driven L-SCC showed a very high specificity of $100 \%$ compared with
93\% in HPV-driven OP-SCC (Holzinger et al, 2013) and 97\% in $\mathrm{CxCa}$ (Halec et al, 2012).

All three HPV-driven L-SCC were $\mathrm{p} 16_{\text {high }}$, as $\mathrm{p} 16_{\text {high }}$ per se was part of our definition of HPV-driven tumours. At contrary, only 1 of the 72 non-HPV-driven/HPV DNA - L-SCC was p16 high. This low frequency of $\mathrm{p} 16^{\mathrm{INK} 4 \mathrm{a}}$ upregulation agrees with previous data (Yuen et al, 2002) and separates non-HPV-driven laryngeal from non-HPV-driven OP-SCC in which p16 ${ }^{\text {INK4a }}$ upregulation was found in up to $20 \%$ (Holzinger et al, 2012) or in up to $14 \%$ in HPV DNA OP-SCC (Smith et al, 2008; Hoffmann et al, 2010; Liang et al, 2012).

Low $\mathrm{pRb}$ expression, also being part of our definition of HPVdriven tumour, was observed in all HPV-driven L-SCC. Among 72 non-HPV-driven/HPV DNA - L-SCC, $42 \%$ were $\mathrm{pRb}_{\text {low. This }}$ again separates non-HPV-driven laryngeal from non-HPV-driven OP-SCC, of which only $14 \%$ were $\mathrm{pRb}_{\text {low }}$ (Holzinger et al, 2012).

Finally, $\mathrm{p} 53_{\text {low }}$ and $\mathrm{CyD} 1_{\text {low }}$ seem not to be reliable markers for HPV-driven L-SCC. Although sensitivity of p53 for HPV-driven L-SCC appears sufficient (all HPV-driven L-SCC were p53 ${ }_{\text {low }}$ ), specificity was very low as $75 \%$ of non-HPV-driven/HPV DNA L-SCC also demonstrated with p53 low. Low CyD1 expression was observed in two of the three HPV-driven, but also in $50 \%$ of nonHPV-driven/HPV DNA - L-SCC. These findings are in agreement with $\mathrm{CxCa}$ and OP-SCC studies analysing these four IHC markers using the same staining protocols and evaluation criteria, which showed that $\mathrm{CyD} 1_{\text {low }}$ and $\mathrm{p} 53_{\text {low }}$ had the lowest sensitivities for HPV-driven tumours (Halec et al, 2012; Holzinger et al, 2013).

For IHC analyses FFPE biopsies are essential. However, the fixation process is known to negatively affect nucleic-acid integrity (Xie et al, 2011). In our study, validity of DNA extracted from FFPE biopsies (78\%) was significantly lower than when extracted from DFT biopsies (100\%). Validity of RNA from FFPE biopsies (94\%) and from DFT biopsies (100\%) was not significantly different. DNA and RNA invalidity was strongly associated with collection period before the end of 1995 . Nine of the 10 patients with invalid DNA and both patients with invalid RNA were from this period, which represents $39 \%$ of all patients. Factors contributing to the lower fraction of RNA- vs DNA-valid FFPEderived samples could be: (a) longer BSGP5 + $6+-$ PCR/MPG amplicon size ( $150 \mathrm{bp}$ for HPV and $208 \mathrm{bp}$ for $\beta$-globin DNA $v s$ 65-75 bp for HPV and 81 bp for ubiquitin C cDNA) and (b) higher copy-numbers per cell of the HPV and ubiquitin C mRNA.

By using a combination of four viral and surrogate markers, our study provides a robust biological evidence for the existence of truly HPV-driven L-SCC. Despite the relatively large case series analysed here, the low frequency of these HPV-driven tumours did not allow to address the question whether like in OP-SCC also in L-SCC HPV-driven tumours differ significantly in biological and clinical characteristics, especially better response to treatment and better survival. These questions can only be addressed in considerably larger, multicentric, collaborative studies.

\section{ACKNOWLEDGEMENTS}

We thank Jochen Hess for support, Antje Schuhmann, Ines Kaden and Nataly Henfling for excellent technical assistance, Laia Alemany and Maria Alejo for assistance in IHC staining, and Niels Grabe and Bernd Lahrmann for scanning of IHC slides. This study was funded in part by the European Commission, Grant HPV-AHEAD (FP7-HEALTH-2011-282562) to MP. DHol was supported by a PhD grant of the German Research Foundation (DFG), Graduiertenkolleg 793: 'Epidemiology of communicable and chronic, noncommunicable diseases and their interrelationships'. MP and MS have received research support through cooperation contracts of DKFZ with Roche and Qiagen in the field of development of HPV diagnostics. 


\section{CONFLICT OF INTEREST}

The authors declare no conflict of interest.

\section{AUTHOR CONTRIBUTIONS}

$\mathrm{GH}, \mathrm{MP}, \mathrm{FXB}$ planned the study design and performed data collection and data interpretation. GH, DHol, MS, DH, BL, CF, GD conceived and carried out experiments, collected the data and analysed the data. GH, DHol, FXB, MP performed literature search and generation of figures. All authors were involved in writing the paper and had final approval of the submitted and published versions.

\section{DISCLAIMER}

MS, DH, FXB and MP are listed on a DKFZ patent application to the European Patent Office (Europe patent application EP11175242.4).

\section{REFERENCES}

Almadori G, Cadoni G, Cattani P, Posteraro P, Scarano E, Ottaviani F, Paludetti G, Maurizi M (1996) Detection of human papillomavirus DNA in laryngeal squamous cell carcinoma by polymerase chain reaction. Eur J Cancer 32A(5): 783-788.

Andl T, Kahn T, Pfuhl A, Nicola T, Erber R, Conradt C, Klein W, Helbig M, Dietz A, Weidauer H, Bosch FX (1998) Etiological involvement of oncogenic human papillomavirus in tonsillar squamous cell carcinomas lacking retinoblastoma cell cycle control. Cancer Res 58(1): 5-13.

Bernard HU, Burk RD, Chen Z, van Doorslaer K, Hausen H, de Villiers EM (2010) Classification of papillomaviruses (PVs) based on 189 PV types and proposal of taxonomic amendments. Virology 401(1): 70-79.

Braakhuis BJ, Snijders PJ, Keune WJ, Meijer CJ, Ruijter-Schippers HJ, Leemans CR, Brakenhoff RH (2004) Genetic patterns in head and neck cancers that contain or lack transcriptionally active human papillomavirus. J Natl Cancer Inst 96(13): 998-1006.

Chernock RD, El-Mofty SK, Thorstad WL, Parvin CA, Lewis Jr JS (2009) HPV-related nonkeratinizing squamous cell carcinoma of the oropharynx: utility of microscopic features in predicting patient outcome. Head Neck Pathol 3(3): 186-194.

Chernock RD, Wang X, Gao G, Lewis Jr. JS, Zhang Q, Thorstad WL, El-Mofty SK (2012) Detection and significance of human papillomavirus, $\mathrm{CDKN} 2 \mathrm{~A}(\mathrm{p} 16)$ and $\mathrm{CDKN} 1 \mathrm{~A}(\mathrm{p} 21)$ expression in squamous cell carcinoma of the larynx. Mod Pathol 26(2): 223-231.

D'Souza G, Dempsey A (2011) The role of HPV in head and neck cancer and review of the HPV vaccine. Prev Med 53(Suppl 1): S5-S11.

Duray A, Descamps G, Arafa M, Decaestecker C, Remmelink M, Sirtaine N, Ernoux-Neufcoeur P, Mutijima E, Somja J, Depuydt CE, Delvenne P, Saussez S (2011) High incidence of high-risk HPV in benign and malignant lesions of the larynx. Int J Oncol 39(1): 51-59.

Dyson N, Howley PM, Munger K, Harlow E (1989) The human papilloma virus-16 E7 oncoprotein is able to bind to the retinoblastoma gene product. Science 243(4893): 934-937.

El-Mofty SK, Patil S (2006) Human papillomavirus (HPV)-related oropharyngeal nonkeratinizing squamous cell carcinoma: characterization of a distinct phenotype. Oral Surg Oral Med Oral Pathol Oral Radiol Endod 101(3): 339-345.

Garcia-Milian R, Hernandez H, Panade L, Rodriguez C, Gonzalez N, Valenzuela C, Arana MD, Perea SE (1998) Detection and typing of human papillomavirus DNA in benign and malignant tumours of laryngeal epithelium. Acta Otolaryngol 118(5): 754-758.

Gorgoulis VG, Zacharatos P, Kotsinas A, Kyroudi A, Rassidakis AN, Ikonomopoulos JA, Barbatis C, Herrington CS, Kittas C (1999) Human papilloma virus (HPV) is possibly involved in laryngeal but not in lung carcinogenesis. Hum Pathol 30(3): 274-283.

Gottlieb TM, Oren M (1996) p53 in growth control and neoplasia. Biochim Biophys Acta 1287(2-3): 77-102.
Gungor A, Cincik H, Baloglu H, Cekin E, Dogru S, Dursun E (2007) Human papilloma virus prevalence in laryngeal squamous cell carcinoma. $J$ Laryngol Otol 121(8): 772-774.

Halec G, Schmitt M, Dondog B, Sharkhuu E, Wentzensen N, Gheit T, Tommasino M, Kommoss F, Bosch FX, Franceschi S, Clifford G, Gissmann L, Pawlita M (2012) Biological activity of probable/possible high-risk human papillomavirus types in cervical cancer. Int J Cancer 132(1): 63-71.

Hoffmann M, Ihloff AS, Gorogh T, Weise JB, Fazel A, Krams M, Rittgen W, Schwarz E, Kahn T (2010) p16(INK4a) overexpression predicts translational active human papillomavirus infection in tonsillar cancer. Int J Cancer 127(7): 1595-1602.

Hoffmann M, Tribius S, Quabius ES, Henry H, Pfannenschmidt S, Burkhardt C, Gorogh T, Halec G, Hoffmann AS, Kahn T, Rocken C, Haag J, Waterboer T, Schmitt M (2012) HPV DNA, E6 ${ }^{\star}$ I-mRNA expression and p16INK4A immunohistochemistry in head and neck cancer: how valid is p16INK4A as surrogate marker? Cancer Lett 323(1): 88-96.

Holzinger D, Flechtenmacher C, Henfling N, Kaden I, Grabe N, Lahrmann B, Schmitt M, Hess J, Pawlita M, Bosch FX (2013) Identification of oropharyngeal squamous cell carcinomas with active HPV16 involvement by immunohistochemical analysis of the retinoblastoma protein pathway. Int J Cancer; e-pub ahead of print 2 March 2013; doi:10.1002/ijc.28142.

Holzinger D, Schmitt M, Dyckhoff G, Benner A, Pawlita M, Bosch FX (2012) Viral RNA patterns and high viral load reliably define oropharynx carcinomas with active HPV16 involvement. Cancer Res 72(19): 4993-5003.

IARC (2011) Human papillomaviruses. IARC Monogr Eval Carcinog Risks Hum 2011 100B: 1-475.

Jung AC, Briolat J, Millon R, de Reynies A, Rickman D, Thomas E, Abecassis J, Clavel C, Wasylyk B (2010) Biological and clinical relevance of transcriptionally active human papillomavirus (HPV) infection in oropharynx squamous cell carcinoma. Int J Cancer 126(8): 1882-1894.

Kastan MB, Onyekwere O, Sidransky D, Vogelstein B, Craig RW (1991) Participation of $\mathrm{p} 53$ protein in the cellular response to DNA damage. Cancer Res 51(23 Pt 1): 6304-6311.

Klaes R, Friedrich T, Spitkovsky D, Ridder R, Rudy W, Petry U, DallenbachHellweg G, Schmidt D, von Knebel Doeberitz M (2001) Overexpression of p16(INK4A) as a specific marker for dysplastic and neoplastic epithelial cells of the cervix uteri. Int J Cancer 92(2): 276-284.

Kreimer AR, Clifford GM, Boyle P, Franceschi S (2005) Human papillomavirus types in head and neck squamous cell carcinomas worldwide: a systematic review. Cancer Epidemiol Biomarkers Prev 14(2): 467-475.

Lewis Jr JS, Ukpo OC, Ma XJ, Flanagan JJ, Luo Y, Thorstad WL, Chernock RD (2012) Transcriptionally-active high-risk human papillomavirus is rare in oral cavity and laryngeal/hypopharyngeal squamous cell carcinomas: a tissue microarray study utilizing E6/E7 mRNA in situ hybridization. Histopathology 60(6): 982-991.

Liang C, Marsit CJ, McClean MD, Nelson HH, Christensen BC, Haddad RI, Clark JR, Wein RO, Grillone GA, Houseman EA, Halec G, Waterboer T, Pawlita M, Krane JF, Kelsey KT (2012) Biomarkers of HPV in head and neck squamous cell carcinoma. Cancer Res 72(19): 5004-5013.

Lindquist D, Romanitan M, Hammarstedt L, Nasman A, Dahlstrand H, Lindholm J, Onelov L, Ramqvist T, Ye W, Munck-Wikland E, Dalianis T (2007) Human papillomavirus is a favourable prognostic factor in tonsillar cancer and its oncogenic role is supported by the expression of E6 and E7. Mol Oncol 1(3): 350-355.

Massimi P, Banks L (1997) Repression of p53 transcriptional activity by the HPV E7 proteins. Virology 227(1): 255-259.

Mellin H, Dahlgren L, Munck-Wikland E, Lindholm J, Rabbani H, Kalantari M, Dalianis T (2002) Human papillomavirus type 16 is episomal and a high viral load may be correlated to better prognosis in tonsillar cancer. Int J Cancer 102(2): 152-158.

Morshed K, Polz-Dacewicz M, Szymanski M, Polz D (2008) Short-fragment PCR assay for highly sensitive broad-spectrum detection of human papillomaviruses in laryngeal squamous cell carcinoma and normal mucosa: clinico-pathological evaluation. Eur Arch Otorhinolaryngol 265(Suppl 1): S89-S96.

Muscat JE, Wynder EL (1992) Tobacco, alcohol, asbestos, and occupational risk factors for laryngeal cancer. Cancer 69(9): 2244-2251.

Pannone G, Sanguedolce F, Santoro A, Fierro P, Panetti M, Fierro D, Maiello F, De Maria S, Giannattasio A, Serpico R, Lo Muzio L, Metafora S, Bufo P (2010) Detection of novel Human papilloma virus type 82 in laryngeal cancer: case report. Auris Nasus Larynx 37(5): 648-650. 
Perez-Ayala M, Ruiz-Cabello F, Esteban F, Concha A, Redondo M, Oliva MR, Cabrera T, Garrido F (1990) Presence of HPV 16 sequences in laryngeal carcinomas. Int J Cancer 46(1): 8-11.

Reimers N, Kasper HU, Weissenborn SJ, Stutzer H, Preuss SF, Hoffmann TK, Speel EJ, Dienes HP, Pfister HJ, Guntinas-Lichius O, Klussmann JP (2007) Combined analysis of HPV-DNA, p16 and EGFR expression to predict prognosis in oropharyngeal cancer. Int J Cancer 120(8): 1731-1738.

Rischin D, Young RJ, Fisher R, Fox SB, Le QT, Peters LJ, Solomon B, Choi J, O'Sullivan B, Kenny LM, McArthur GA (2010) Prognostic significance of pl6INK4A and human papillomavirus in patients with oropharyngeal cancer treated on TROG 02.02 phase III trial. J Clin Oncol 28(27): 4142-4148.

Salam M, Rockett J, Morris A (1995) The prevalence of different human papillomavirus types and p53 mutations in laryngeal carcinomas: is there a reciprocal relationship? Eur J Surg Oncol 21(3): 290-296.

Scheffner M, Werness BA, Huibregtse JM, Levine AJ, Howley PM (1990) The E6 oncoprotein encoded by human papillomavirus types 16 and 18 promotes the degradation of p53. Cell 63(6): 1129-1136.

Schlecht NF, Brandwein-Gensler M, Nuovo GJ, Li M, Dunne A, Kawachi N, Smith RV, Burk RD, Prystowsky MB (2011) A comparison of clinically utilized human papillomavirus detection methods in head and neck cancer. Mod Pathol 24(10): 1295-1305.

Schmitt M, Bravo IG, Snijders PJ, Gissmann L, Pawlita M, Waterboer T (2006) Bead-based multiplex genotyping of human papillomaviruses. J Clin Microbiol 44(2): 504-512.

Schmitt M, Dalstein V, Waterboer T, Clavel C, Gissmann L, Pawlita M (2010) Diagnosing cervical cancer and high-grade precursors by HPV16 transcription patterns. Cancer Res 70(1): 249-256.

Schmitt M, Depuydt C, Benoy I, Bogers J, Antoine J, Arbyn M, Pawlita M (2013) Prevalence and viral load of 51 genital human papillomavirus types and three subtypes. Int J Cancer 132(10): 2395-2403.

Schmitt M, Dondog B, Waterboer T, Pawlita M (2008) Homogeneous amplification of genital human alpha papillomaviruses by PCR using novel broad-spectrum GP5 + and GP6 + primers. J Clin Microbiol 46(3): 1050-1059.

Si-Mohamed A, Badoual C, Hans S, Pere H, Tartour E, Brasnu D (2012) An unusual human papillomavirus type 82 detection in laryngeal squamous cell carcinoma: case report and review of literature. J Clin Virol 54(2): 190-193.

Skyldberg B, Fujioka K, Hellstrom AC, Sylven L, Moberger B, Auer G (2001) Human papillomavirus infection, centrosome aberration, and genetic stability in cervical lesions. Mod Pathol 14(4): 279-284.

Smeets SJ, Hesselink AT, Speel EJ, Haesevoets A, Snijders PJ, Pawlita M, Meijer CJ, Braakhuis BJ, Leemans CR, Brakenhoff RH (2007)

A novel algorithm for reliable detection of human papillomavirus in paraffin embedded head and neck cancer specimen. Int J Cancer 121(11): 2465-2472.

Smith EM, Wang D, Kim Y, Rubenstein LM, Lee JH, Haugen TH, Turek LP (2008) P16INK4a expression, human papillomavirus, and survival in head and neck cancer. Oral Oncol 44(2): 133-142.

Sotlar K, Stubner A, Diemer D, Menton S, Menton M, Dietz K, Wallwiener D, Kandolf R, Bultmann B (2004) Detection of high-risk human papillomavirus E6 and E7 oncogene transcripts in cervical scrapes by nested RT-polymerase chain reaction. J Med Virol 74(1): 107-116.

Syrjanen S, Syrjanen K, Mantyjarvi R, Collan Y, Karja J (1987) Human papillomavirus DNA in squamous cell carcinomas of the larynx demonstrated by in situ DNA hybridization. ORL J Otorhinolaryngol Relat Spec 49(4): 175-186.

Torrente MC, Rodrigo JP, Haigentz Jr. M, Dikkers FG, Rinaldo A, Takes RP, Olofsson J, Ferlito A (2011) Human papillomavirus infections in laryngeal cancer. Head Neck 33(4): 581-586.

Tsuda H, Hashiguchi Y, Nishimura S, Kawamura N, Inoue T, Yamamoto K (2003) Relationship between HPV typing and abnormality of G1 cell cycle regulators in cervical neoplasm. Gynecol Oncol 91(3): 476-485.

van Houten VM, Snijders PJ, van den Brekel MW, Kummer JA, Meijer CJ, van Leeuwen B, Denkers F, Smeele LE, Snow GB, Brakenhoff RH (2001) Biological evidence that human papillomaviruses are etiologically involved in a subgroup of head and neck squamous cell carcinomas. Int $J$ Cancer 93(2): 232-235.

Wiest T, Schwarz E, Enders C, Flechtenmacher C, Bosch FX (2002) Involvement of intact HPV16 E6/E7 gene expression in head and neck cancers with unaltered p53 status and perturbed pRb cell cycle control. Oncogene 21(10): 1510-1517.

Xie R, Chung JY, Ylaya K, Williams RL, Guerrero N, Nakatsuka N, Badie C, Hewitt SM (2011) Factors influencing the degradation of archival formalin-fixed paraffin-embedded tissue sections. J Histochem Cytochem 59(4): 356-365.

Yuen PW, Man M, Lam KY, Kwong YL (2002) Clinicopathological significance of p16 gene expression in the surgical treatment of head and neck squamous cell carcinomas. J Clin Pathol 55(1): 58-60.

zur Hausen H (2006) Perspectives of contemporary papillomavirus research. Vaccine 24(Suppl 3): S3/iii-S3/iii.

This work is published under the standard license to publish agreement. After 12 months the work will become freely available and the license terms will switch to a Creative Commons AttributionNonCommercial-Share Alike 3.0 Unported License.

Supplementary Information accompanies this paper on British Journal of Cancer website (http://www.nature.com/bjc) 